\title{
THE COVID-19 PANDEMIC AND THE CHANGES IN CONSUMER HABITS AND BEHAVIOR
}

\author{
A PANDEMIA DE COVID-19 E AS MUDANÇAS NOS \\ HÁBITOS E COMPORTAMENTOS DO CONSUMIDOR
}

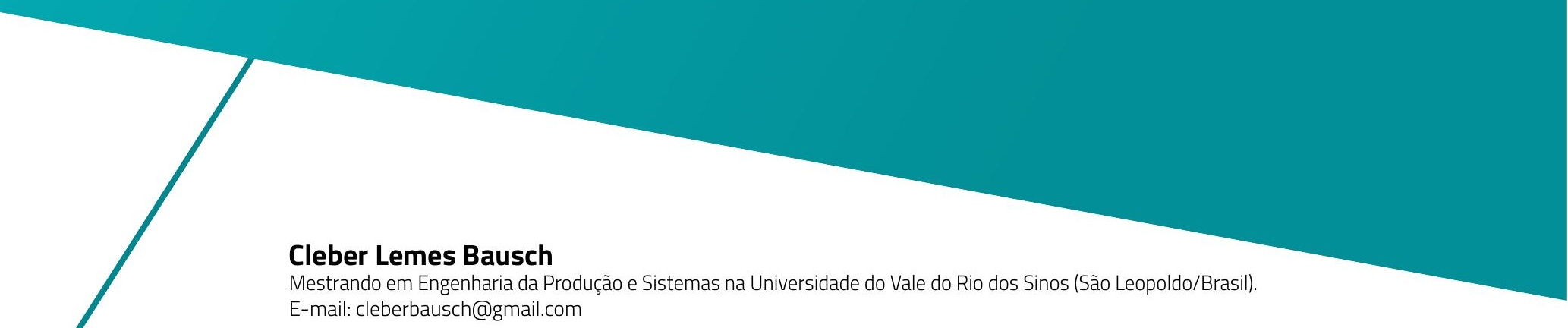

E-mail: cleberbausch@gmail.com

\section{Gabriel Sperandio Milan}

Pós-Doutor em Administração - Marketing pela Universidade Federal do Rio Grande do Sul (Porto Alegre/Brasil).

Professor na Universidade do Vale do Rio dos Sinos (São Leopoldo/Brasil).

E-mail: gsmilan@unisinos.br

\section{Ana Paula Graciola}

Pós-Doutoranda em Engenharia da Produção e Sistemas na Universidade do Vale do Rio dos Sinos (São Leopoldo/Brasil).

E-mail: anagraciola@gmail.com

\section{Luciene Eberle}

Pós-Doutoranda em Engenharia da Produção e Sistemas na Universidade do Vale do Rio dos Sinos (São Leopoldo/Brasil).

E-mail: luciene.eberle@gmail.com

\section{Suélen Bebber}

Doutoranda em Administração na Universidade de Caxias do Sul (Caxias do Sul/Brasil).

E-mail: beber.suelen@gmail.com

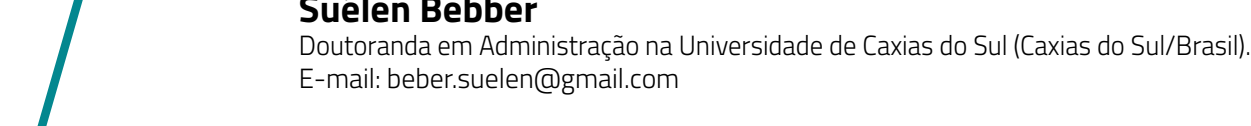

Recebido em: 6 de abril de 2021

Aprovado em: 14 de julho de 2021

Sistema de Avaliação: Double Blind Review

RGD | v. 18 | n. 3 | p. 03-25 | set./dez. 2021

DOI: https://doi.org/10.25112/rgd.v18i3.2846 


\section{ABSTRACT}

In a short time, the COVID-19 pandemic transformed people's behavior, undermining firms and businesses and changing the global economy. In this context, the study aimed to understand the impacts the COVID-19 pandemic caused on consumer behavior. The research method adopted was the literature review, investigating the Scopus and Web of Science databases, two of the main scientific databases. A total of 205 articles published in 2020 were identified, and, based on the proposed criteria, 30 studies showed high adherence to the topic and contributed to the understanding of changes in consumer habits and behavior. The main themes identified were: e-commerce growth, panic buying, repressed demand and stricken sectors, do-it-yourself, increased apps usage, machine learning methods, data internet security, and online marketing and shopping platforms.

Keywords: COVID-19 Pandemic. Consumer Behavior. New Consumption Habits. Market Perspectives. Literature Review.

\section{RESUMO}

Em pouco tempo, a pandemia de COVID-19 transformou o comportamento das pessoas, prejudicando empresas e negócios e mudando a economia global. Nesse contexto, o estudo teve como objetivo compreender os impactos que a pandemia de COVID-19 causou no comportamento do consumidor. O método de pesquisa adotado foi a revisão de literatura, investigando as bases de dados Scopus e Web of Science, duas das principais bases de dados científicas. Foram identificados 205 artigos publicados em 2020 e, com base nos critérios propostos, 30 estudos demonstraram alta aderência ao tema e contribuíram para a compreensão das mudanças nos hábitos e comportamento do consumidor. Os principais temas identificados foram: crescimento do comércio eletrônico, compra em pânico, demanda reprimida e setores afetados, faça você mesmo, aumento do uso de aplicativos, métodos de aprendizado de máquina, segurança de dados na Internet e plataformas de marketing e compras on-line.

Palavras-chave: Pandemia de COVID-19. Comportamento do Consumidor. Novos Hábitos de Consumo. Perspectivas de Mercado. Revisão da Literatura. 


\section{INTRODUCTION}

Individuals' attitudes and behaviors were severely affected by the COVID-19 pandemic, which quickly transformed people's behavior. Humanity is in a learning process in the face of this new reality, although we have not faced the totality of its effects. Sheth (2020) warned that the socioeconomic consequences of the pandemic are serious. The public health measures adopted have impacted the economy and consumers' habits and purchase behavior, instigated by the need for social distancing. As a result, acceleration in the development of new consumption habits and behaviors has been observed.

Due to people's movement restriction, social distancing, the lockdown (KERIGAN, 2020), the need to adapt purchases, and the conveniences that the evolution of technology and digitalization are providing, even if the old habits return, they will likely be modified by the creation of new regulations and procedures. Similarly, it is possible that a large part of the purchasing habits and behaviors developed during the pandemic remain and that online purchases have a higher percentage than previously perceived $(\mathrm{SHETH}$, 2020).

It is a fact that the COVID-19 pandemic surprised the world, causing turbulence to society and business environments, affecting the world economy, as rigorous blocking measures changed daily life and consumer behavior (BAICU et al., 2020; HOSSAIN, 2021). Thus, environmental factors have become unpredictable, and companies' ability to adapt to this new economic context makes the difference for business survival (OANA, 2020; HOSSAIN, 2021). This scenario has been causing insecurity in people, emerging the concern with their health and the health of their families, and the perception of risk to the financial stability and the economy as a whole. Furthermore, these aspects are among the main anxieties that the COVID-19 pandemic has caused in people. How individuals perceive risk and their attitude towards it changes consumer habits and behavior (OANA, 2020). Therefore, this scenario instills individuals' feelings and emotions (SOSCIA, 2013), which will, logically, impact consumer habits and behavior in the coming years (HOEKSTRA; LEEFLANG, 2020).

Other epidemics were experienced in the past, and many restrictions that brought difficulties were imposed previously, such as restrictions on trade, movement of people and goods, limitations on exports, and interruptions in production (HASSAN et al., 2020; KAUR; MALIK, 2020). Public health organizations and experts in the field warned, in 2017, that the emergence of a new pandemic would be close and that no nation would be fully prepared to face it. Even so, nations were surprised by the current pandemic (OANA, 2020). When they came across such circumstances, people became more cautious. They began to avoid public environments to reduce the risk of contagion, which impacted consumption, highlighting 
the need to formulate policies to minimize or neutralize such negative impacts on the economy (KAUR; MALIK, 2020).

Donthu and Gustafsson (2020) commented that the COVID-19 outbreak reminds us that disasters that occur rarely and happened in the past may occur again in the future. Although we cannot avoid them, we must be prepared to mitigate their effects. Natural disasters, global pandemics, and regional or global conflicts have already disrupted production, supply chains, and consumption (SHETH, 2020). On this horizon, Kaur and Malik (2020) stated that extreme events directly influence consumer behavior. In any case, many questions remain unanswered in this pandemic. Even if humanity has already experienced situations of this kind, estimating the real consequences is still something complex, such as answering what the long-term social, economic, and behavioral impacts will be, and even whether we will return to a condition of life and consumption before the pandemic or whether we will address the so-called "new normal".

Therefore, understanding the COVID-19 pandemic impacts on consumer behavior is justified due to the economic difficulties experienced worldwide, in which companies seek ways to adapt to the difficult moment and keep their operations to a minimum. Understanding the changes in consumer behavior can support corporations to reorganize themselves to overcome this moment and the difficulties imposed, in addition to collaborating for future analysis, that consider between what will return to the condition before the pandemic and the factors that may compose the "new normal".

From this perspective, this study was guided by the following central research question: What impacts have the COVID-19 pandemic caused and may cause on consumer behavior? Therefore, the study aimed to understand the impacts that the COVID-19 pandemic caused on consumer behavior from a literature review.

\section{RESEARCH METHOD}

This study was developed through a literature review (HENNINK et al., 2011; REMLER; VAN RYZIN, 2011; SCOTT; GARNER, 2013), presenting elements for public and private corporations' managers to direct their strategies, actions, and investments, as well as researchers, who can base new research in this area. The literature review followed a critical or integrative approach (SNYDER, 2019) to synthesize and compare the existing literature and adherent to the subject researched, providing the basis for new theoretical references and analysis perspectives (TORRACO, 2005).

A critical literature review does not follow a specific protocol or standard. However, it aims to examine the literature and analyze critically, presenting an overview and shared evidence in a particular 
area of research, discovering which elements have effects on the phenomenon studied, documenting the techniques and the process of analysis in a transparent way, if they are objectives of the research (Snyder, 2019). Thus, under the recommendations of Snyder (2019), Ramdhani et al. (2014), and Torraco (2005), the search in the databases followed the following steps: (i) design, (ii) data collection, (iii) data analysis and structure and, (iv) writing (presentation) of the research results.

\subsection{DESIGN}

At this stage, an analysis of the purpose, the research contribution, and the method and strategy of data search were carried out (SNYDER, 2019). The search proposal was to use the terms "consumer behavior" and "COVID-19 pandemic" based on the topic, the central research question, and the research objective. In order to have a wide range of literature on the subject, the following variants were defined: "consumer behavior" or "consumer behaviour", to search for terms used in the American and British English languages, in addition to the terms "COVID-19", "coronavirus", "pandemic", "epidemic", "outbreak" or "disease outbreak".

\subsection{DATA COLLECTION}

Snyder (2019) stated that, in the data collection stage, the research plan developed for the production of an appropriate sample should be defined and validated from the practical plan for selecting studies (articles) and the evaluation and documentation of the search and selection process. For this purpose, two of the primary databases, Scopus and the Web of Science, were searched in January 2021.

To direct the search to the research interest, the filter used in the Scopus database was composed of the terms defined in the previous step: (TITLE-ABS-KEY(("consumer behavior") OR ("consumer behavior")) AND TITLE-ABS-KEY (("COVID-19") OR ("coronavirus") OR ("pandemic") OR ("epidemic") OR ("outbreak") OR ("outbreak disease"))). This search initially resulted in 205 articles. As criteria for adherence to the research topic, the articles published from 2020 onwards were selected in the areas of interest "business, management and accounting", "economics, econometrics and finance", and "engineering", resulting in 45 studies (articles) that met the established search criteria.

In turn, the search conducted in the Web of Science database followed the same criteria used previously, and the filter performed was composed as follows: (All fields: (("consumer behavior") OR ("consumer behavior"))) AND All fields: ((("COVID-19") OR ("coronavirus") OR ("pandemic") OR ("epidemic") OR ("outbreak") OR ("disease outbreak"))), resulting in 90 articles. After the selection of publications from 2020 and in the areas of interest "business", "economics", "management" and "business finance", 25 articles remained as a result of the search criteria. 
The two databases resulted, therefore, 70 studies (articles), which met the search criteria. After analyzing the two databases studies, 20 repeated articles were identified, resulting in 50 articles. The abstracts of the resulting articles were analyzed and selected by level of adherence to the subject, according to the criteria presented in Table 1. As a result, 10 articles had no relationship between consumer behavior and COVID-19 in the abstract. Besides, 03 articles were also discarded due to low adherence to the subject, as consumer behavior and COVID-19 had a low level of importance in the abstract. Other 07 articles showed an average adherence level since, in the abstract, consumer behavior and COVID-19 were not the studies' focus. In this sense, Table 1 is elucidative.

Table 1 - Selection of articles by the level of adherence to the subject in the abstract

\begin{tabular}{clr}
\hline Coding & Description & Results \\
\hline $\mathrm{R}$ & Repeated Article & 20 \\
$\mathrm{NA}$ & $\begin{array}{l}\text { Not Applicable } \\
\text { (Does not relate consumer behavior and COVID-19 in the abstract) }\end{array}$ & 10 \\
$\mathrm{~L}$ & $\begin{array}{l}\text { Low Adherence } \\
\text { (The topic consumer behavior and COVID-19 presented a low adherence in the abstract) }\end{array}$ & 3 \\
$\mathrm{M}$ & $\begin{array}{l}\text { Medium Adherence } \\
\text { (The topic consumer behavior and COVID-19 is not the main theme in the abstract) }\end{array}$ & 7 \\
$\mathrm{H}$ & $\begin{array}{l}\text { High Adherence } \\
\text { (The topic consumer behavior and COVID-19 is the main theme in the abstract) }\end{array}$ & 30 \\
\hline
\end{tabular}

Source: Elaborated by the authors.

Finally, 30 articles presented a high adherence to the subject because the abstract indicated that consumer behavior and COVID-19 were the studies' focus, corroborated throughout the texts. Figure 1 presents the articles coded and analyzed with high adherence to the theme.

Figure 1 - Final list of the selected articles

\begin{tabular}{|c|l|c|}
\hline Coding (*) & \multicolumn{1}{|c|}{ Final Study Titles (or Articles) } & \multicolumn{1}{|c|}{ Authors } \\
\hline A1 & A computational model to predict consumer behaviour during COVID-19 pandemic & Safara (2020) \\
\hline A2 & $\begin{array}{l}\text { The impact of COVID-19 on consumer behavior in retail banking: evidence from } \\
\text { Romania }\end{array}$ & Baicu et al. (2020) \\
\hline A3 & $\begin{array}{l}\text { I'll trade you diamonds for toilet paper: consumer reacting, coping and adapting } \\
\text { behaviors in the COVID-19 pandemic }\end{array}$ & Kirk and Rifkin (2020) \\
\hline A4 & Impact of Covid-19 on consumer behavior: will the old habits return or die? & Sheth (2020) \\
\hline A5 & Effects of COVID-19 on business and research & $\begin{array}{c}\text { Donthu and Gustafsson } \\
\text { (2020) }\end{array}$ \\
\hline
\end{tabular}




\begin{tabular}{|c|c|c|}
\hline A6 & $\begin{array}{l}\text { The impact of the current crisis generated by the COVID-19 pandemic on consumer } \\
\text { behavior }\end{array}$ & Oana (2020) \\
\hline A7 & $\begin{array}{l}\text { Consumer behaviour during crises: preliminary research on how coronavirus } \\
\text { has manifested consumer panic buying, herd mentality, changing discretionary } \\
\text { spending and the role of the media in influencing behaviour }\end{array}$ & Loxton et al. (2020) \\
\hline A8 & $\begin{array}{l}\text { Malaysians' popular online shopping websites during movement control order } \\
\text { (MCO) }\end{array}$ & Khairunesa (2020) \\
\hline A9 & $\begin{array}{l}\text { The impact of new epidemic situation on short-term choice and long-term } \\
\text { upgrading of consumer behavior }\end{array}$ & Yang et al. (2020) \\
\hline A10 & Understanding the psychology behind panic buying: a grounded theory approach & Kaur and Malik (2020) \\
\hline A11 & $\begin{array}{l}\text { Changing grocery shopping behaviours among Chinese consumers at the outset of } \\
\text { the COVID-19 outbreak }\end{array}$ & Li et al. (2020) \\
\hline A12 & $\begin{array}{l}\text { COVID-19 generation: a conceptual framework of the consumer behavioral shifts } \\
\text { to be caused by the COVID-19 pandemic }\end{array}$ & Russell and Cheryl (2021) \\
\hline A13 & Effects of COVID-19 on consumer behavior: Ecuador case & Ortega-Vivanco (2020) \\
\hline A14 & $\begin{array}{l}\text { A study on the COVID-19 awareness affecting the consumer perceived benefits of } \\
\text { online shopping in Vietnam }\end{array}$ & Van Kien et al. (2020) \\
\hline A15 & $\begin{array}{l}\text { Fear, lockdown, and diversion: comparing drivers of pandemic economic decline } \\
2020\end{array}$ & $\begin{array}{l}\text { Goolsbee and Syverson } \\
\text { (2020) }\end{array}$ \\
\hline A16 & $\begin{array}{l}\text { Weighting bias and inflation in the time of COVID-19: evidence from Swiss } \\
\text { transaction data }\end{array}$ & Seiler (2020) \\
\hline A17 & Time intervention in COVID-19 and panic buying & Prentice et al. (2020) \\
\hline A18 & $\begin{array}{l}\text { The coronavirus' effects on consumer behavior and supermarket activities: insights } \\
\text { from Greece and Sweden }\end{array}$ & Anastasiadou et al. (2020) \\
\hline A19 & Examining food purchase behavior and food values during the COVID-19 pandemic & Ellison et al. (2021) \\
\hline A20 & World oil market: the pandemics will bring global peak oil demand closer & Kopytin (2020) \\
\hline A21 & $\begin{array}{l}\text { Online food delivery services and behavioural intention - a test of an integrated } \\
\text { TAM and TPB framework }\end{array}$ & Troise et al. (2021) \\
\hline A22 & $\begin{array}{l}\text { The consumer in lockdown: consumer-merchant payment in a mobility- } \\
\text { constrained environment }\end{array}$ & Kerigan (2020) \\
\hline A23 & $\begin{array}{l}\text { COVID-19 quarantine and consumer behavior that change the trends of business } \\
\text { sustainability development }\end{array}$ & Hassan et al. (2020) \\
\hline A24 & $\begin{array}{l}\text { COVID-19 and retail grocery management: insights from a broad-based consumer } \\
\text { survey }\end{array}$ & Wang et al. (2020) \\
\hline A25 & COVID-19 virus outbreak lockdown: what impacts on household food wastage? & Jribi et al. (2020) \\
\hline
\end{tabular}




\section{Gestãoe \\ Desenvolvimento}

\begin{tabular}{|c|l|c|}
\hline A26 & COVID-19 crisis in the Netherlands: "only together we can control Corona" & $\begin{array}{c}\text { Antonides and Van } \\
\text { Leeuwen (2020) }\end{array}$ \\
\hline A27 & Consumer attitudes towards flying amidst growing climate concern & Cocolas et al. (2020) \\
\hline A28 & Using internet as a solution for sales in COVID-19 pandemic: e-commerce & $\begin{array}{c}\text { Gabriel and Loredana } \\
\text { (2020) }\end{array}$ \\
\hline A29 & $\begin{array}{l}\text { Online food delivery portals during COVID-19 times: an analysis of changing } \\
\text { consumer behavior and expectations }\end{array}$ & $\begin{array}{c}\text { Dsouza and Sharma } \\
\text { (2020) }\end{array}$ \\
\hline A30 & Understanding panic buying during COVID-19: a text analytics approach & Barnes et al. (2020) \\
\hline
\end{tabular}

\section{Legend: (*) A: Article (or paper).}

\section{Source: Elaborated by the authors}

Figure 2, in turn, presents a summary of the application of the research method used in this study and the respective selection criteria of the studies (articles), which composed the final sample (see Figure 1).

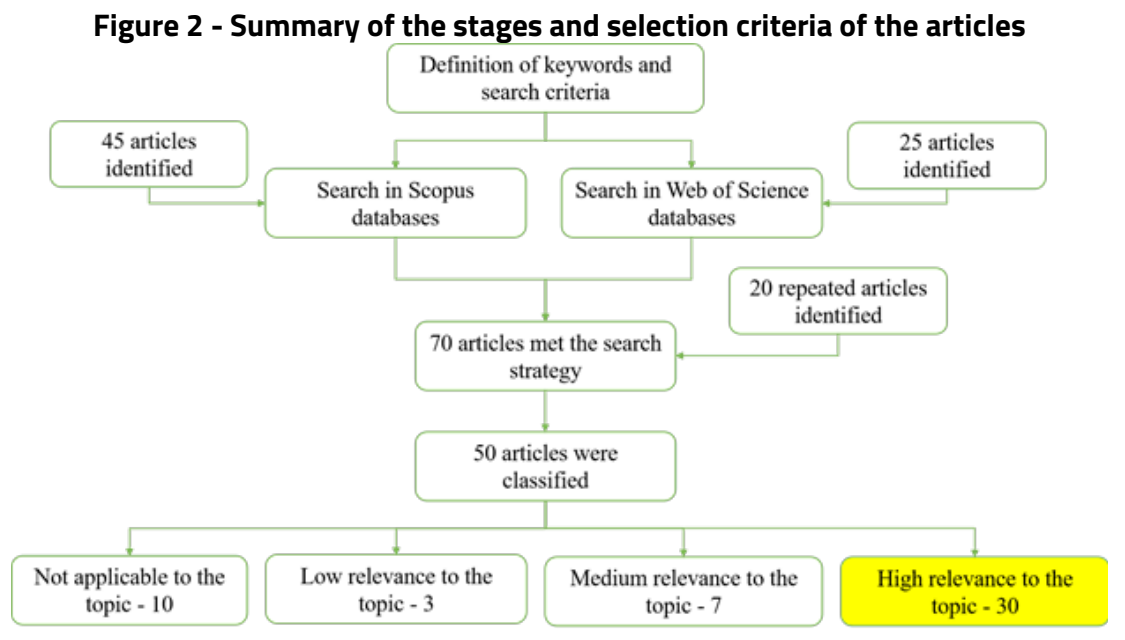

Source: Elaborated by the authors

\subsection{DATA ANALYSIS AND STRUCTURE}

At this stage, an analysis of the selected articles and the collection of relevant information to conduct the study was carried out, abstracting the information that did not meet the research objective, according to the recommendations found in the literature (SNYDER, 2019). The articles were entirety analyzed, identifying the main topics and coding the respective studies (articles). 


\subsection{WRITING (PRESENTATION) OF RESEARCH RESULTS}

The last stage of the research defines the criteria for the elaboration of the developed content, considering the clarity of the study motivation and research objective, results presentation, contribution of the literature review, and whether the level of information provided is sufficient and appropriate to allow readers to evaluate the content quality (SNYDER, 2019). The results of the analysis and collection of information are presented and discussed in the following section.

\section{RESEARCH FINDINGS AND DISCUSSION OF MAIN RESULTS}

The research findings were divided into two main axes. The first axis presents the behavioral factors that impacted the economy and consumption characteristics, and the second addresses the impact of technologies on consumer behavior and the economy during the COVID-19 pandemic explicitly.

\subsection{PANIC BUYING: FOOD AND OTHER PRODUCTS STOCK DURING THE PANDEMIC}

In periods of natural disasters or crises caused by man or nature, people increase the purchase of storable goods. In fact, at the beginning of the pandemic by COVID-19, panic buying occurred on a global scale. This behavior is explained as storing various goods for the future, in larger volumes than necessary for the present need. Such behavior is called hoarding behavior, considered instinctive as a threat is perceived and is motivated by the fear of being unprepared for the anticipated scenario. In panic buying, consumers tend to stock up on water, staple foods, and other items that they understand can sustain them through the period of crisis. In a reaction of fear to perceived and real scarcity, this sudden change in consumer behavior occurs in emergencies as a mass psychological phenomenon looking for survival. However, consumers accumulation of products on a large scale results in a lack of product supply in the market and a consequent increase in average prices (ANASTASIADOU et al., 2020; ANTONIDES; VAN LEEUWEN, 2020; BARNES et al., 2020; DONTHU; GUSTAFSSON, 2020; KAUR; MALIK, 2020; KIRK; RIFKIN, 2020; LI et al., 2020; LOXTON et al., 2020; PRENTICE et al., 2020; ELLISON et al., 2021).

The motivation to go through isolation or even lockdown, more pleasantly, to take care of the own health and that of the people close, led consumers to stock hygiene, cleaning and disinfection products, medicines, food, and beverages, leading to a considerable increase in demand (JRIBI et al., 2020; OANA, 2020; HOSSAIN, 2021). The scarcity of products and the uncertainty of future supply have added to the emergence of an irregular market, in which unauthorized intermediaries have purchased large quantities of products. This has led to higher prices, such as personal protective equipment for healthcare professionals and N95 protective masks (SHETH, 2020). On the other hand, non-essential goods demand such as 
clothes, shoes, and household appliances, at the beginning of the pandemic and with the closing of trade, experienced the sales fell, highlighting the need for models to predict consumer behavior and plan the survival of companies that marketed these types of products (SAFARA, 2020).

\subsection{REPRESSED DEMAND AND NEGATIVE ECONOMIC SECTORS TOUCHED}

In moments of uncertainty, the purchases of non-essential products are usually postponed combined with store closure to comply with the containment measures imposed, which would be the most prominent causes for the drop in demand. The consumer turned to essential need items, and the impossibility of buying products in physical stores added to the consumer's lack of confidence, made the sales fall. Two factors that influenced the loss of confidence were the soaring unemployment rate and the recession economy (GOOLSBEE; SYVERSON, 2020; LI et al., 2020; LOXTON et al., 2020; ORTEGAVIVANCO, 2020; SEILER, 2020; SHETH, 2020; YANG et al., 2020).

Sheth (2020) points out that the postponement of non-essential products purchases was more associated with high-cost durable goods, such as cars and residential real estate. According to Kopytin (2020), even consumption during the pandemic was affected. On the other hand, Seiler (2020) believed that the efficient teleworking conditions created are likely to be maintained, which will negatively impact restaurants that will need to adapt to post-pandemic due to consumer habits and behavior changes.

The economic sectors that need the consumers' physical presence, such as hotels, tourism, transportation, and entertainment, presented the highest unemployment rates. According to Donthu and Gustafsson (2020), airlines, for example, reduced their workforce by $90 \%$. Conferences, exhibitions, and events of all kinds were suddenly canceled, besides cab services, beauty parlors, and fitness centers, which had to stop their activities. Moreover, this will imply, for example, in airlines and airports, new practices and changes in their operations to provide a safer and more reliable way of flying for passengers (COCOLA et al., 2020).

\subsection{DO-IT-YOURSELF!}

The imposition of social distance and the need to stay at home motivated people to perform activities they would not do at other times. "Do-it-yourself - DIY" activities grew during the pandemic, as people were unsure about hiring professionals to perform activities in their homes. For Kirk and Rifkin (2020), many consumers initiated such projects and household activities like cooking and gardening. People are more confident in cooking, and this is something that can give them pleasure. The authors pointed out that sales of building materials have skyrocketed, and the mention in social media for painting and renovation doubled in the first two weeks of March 2020. Besides, Russell and Cheryl (2021) noted that people's 
need to stay at home, added to restaurant closure, made the ability to prepare their own meals a new practice. In turn, Ellison et al. (2021) cited rising unemployment as a factor in giving family members more time to plan and prepare meals.

Do-it-yourself (DIY) practice by a group of people involves creativity and personality when developing their products. Saving money is not the essential motivation for the present do-it-yourself behavior (KHADEMI-VIDRA; BUJDOSÓ, 2020). Even though during or after the pandemic there was an increase in do-it-yourself, it was possible to verify that, according to Steven (1997), this term appeared in 1912 for the first time, in the literature referring to activities carried out by non-professional practitioners involving activities in home improvement and maintenance (WILLIAMS, 2004; KHADEMI-VIDRA; BUJDOSÓ, 2020).

Wolf and McQuitty (2013) point out that DIY involves activities in which individuals create, compose, recreate, or reconstruct objects with non-processed or semi-processed materials (KHADEMI-VIDRA; BUJDOSÓ, 2020). It is possible to relate consumer behavior during the pandemic and post-pandemic to DIY. Thus, market conditions, lack of goods, limited access, or the low quality of services can lead to the practice of "Do-it-yourself!". However, consumers can present do-it-yourself behavior to be distracted, have fun, or express themselves (WOLF; MCQUITTY, 2013; KHADEMI-VIDRA; BUJDOSÓ, 2020), relax when practicing something that is their hobby.

\subsection{E-COMMERCE AND/OR M-COMMERCE GROWTH}

E-commerce and/or M-Commerce were already growing before the pandemic. The advances in technology, the ease of shopping, receiving products at home, and the possibility of increasing free time, made this type of purchase a reality. However, improving the accuracy of forecasting consumer needs and increasing their satisfaction were e-commerce challenges. The orders to block and restrict circulation imposed to maintain social distance and disseminate COVID-19 hampered purchases in physical stores, making it more convenient for consumers to make their purchases online. This is a business trend, both for consumers and companies. Supermarkets, restaurants, electronics, clothing, building and renovation materials, and the automotive industry have strongly adhered to e-commerce, achieving great results (ANASTASIADOU et al., 2020; DSOUZA; SHARMA, 2020; KHAIRUNESA, 2020; KIRK; RIFKIN, 2020; LI et al., 2020; SAFARA, 2020; SHETH, 2020; VAN KIEN et al., 2020; TROISE et al., 2021).

For Oana (2020), due to the established state of emergency, purchasing decisions were predominantly focused on the online environment because of the reduced risk of contact with the virus. The pandemic has served to further engage in electronic payments and e-banking (ANASTASIADOU et al., 2020), used primarily for consumer purchases in e-commerce or m-commerce (KERIGAN, 2020). There has also been a growth in online purchases of ready-to-eat food (WANG et al., 2020) and staple food, such as rice and 
macaroni, canned and frozen products, besides electronic products (PRENTICE et al., 2020), and ready-toeat delivery (TROISE et al., 2021). Khairunesa (2020) has seen a growth in the sale of computer items due to the need to work at home (home office) to meet social distance needs. This new moment in recent history has provided a greater take-up and boost to digital technologies. Even Yang et al. (2020) warned that the pandemic will impact all types of consumer goods and that new forms of consumption are emerging, such as online education (face-to-face remote), online finance, virtual reality, logistics platforms, and online entertainment.

The online marketplace (e-commerce) is hugely competitive, while mobile commerce adds an extra layer to the complexity of the market, but it also arrives as an opportunity for retailers (MCLEAN; WILSON, 2019; TUPIKOVSKAJA-OMOVIE; TYLER, 2020; OMAR et al., 2021). The digital transformation changes the way companies and consumers relate to new technologies and the facilities that new technologies bring together with new behaviors, interactions, and experiences (PAYNE et al., 2008; OMAR et al., 2021). Mobiles have become devices of consumers' daily life, provide enrichment in interactions and serve customers anytime or anywhere (WANG et al., 2015; OMAR et al., 2021). Therefore, amidst the pandemic and the post-pandemic, e-commerce and m-commerce intensified.

\subsection{APPS (ONLINE SHOPPING, MOBILE BANKING, AND COVID-19 GUIDANCE)}

Customers prefer using mobile applications on pandemic days (DIRSEHAN, CANKAT, 2021). $\mathrm{M}$-commerce applications help to facilitate the use of $\mathrm{m}$-commerce. The reasons why people use virtual stores and $\mathrm{m}$-commerce applications to make their purchases (FEDORKO et al., 2018; DIRSEHAN; CANKAT, 2021) contribute to creating new directions and positions for retailers that want to maintain or increase their sales. To Statista (2021a), smartphones or similar platforms increase the users' number. Also, the number of application users who performed downloads increase. Regarding the global level, the number of mobile app downloads was 178 billion in 2017. The expectation is to increase this number to 258 billion in 2022 (STATISTA, 2021a; DIRSEHAN; CANKAT, 2021).

The applications or apps help consumers in several areas. Understanding how consumers behave and providing a service that quickly meets their needs is fundamental to any business (SAFARA, 2020). For Baicu et al. (2020), people's lifestyles changed during the pandemic, and the need for isolation has limited access to various services, encouraging consumers to use online services. Thus, the pandemic had a positive effect on the internet and mobile banking services (BAICU et al., 2020). In addition to greater security, confidence, comfort, and perceived personifications, which support the consumer's purchase decision when using the services, a greater convenience was evidenced. Therefore, identifying the reasons that lead consumers to use purchase or service apps is fundamental to the success of e-commerce and 
online services (SAFARA, 2020; GABRIEL; LOREDANA, 2020). The apps also orientated and provided people information about the pandemic (PRENTICE et al., 2020). In times of pandemic, in conjunction with the development of mobile apps, consumers began to avoid places such as restaurants due to social distancing and other necessary precautions during the pandemic (STATISTA, 2020b; DIRSEHAN; CANKAT, 2021). Technology, in the form of applications, helps to bridge the gap between online and physical channels. Thus, retailers must rethink their competitive advantages (BRYNJOLFSSON et al., 2013; DIRSEHAN; CANKAT, 2021). Furthermore, applications offer different services, flexibility, mobility, and efficiency to consumers (RAO; TROSHANI, 2007; DIRSEHAN; CANKAT, 2021).

\subsection{MACHINE LEARNING METHODS}

Machine learning methods are being used to extract information from online shopping websites and employ techniques to analyze consumer behavior automatically and thus tailor their operations to provide higher quality service, improving efficiency. Artificial intelligence is on the rise and can bring more convenience and effectiveness to online shopping. Online catalogs can help compare products in terms of quality and price level, reducing the time spent by the consumer to make the purchase (SAFARA, 2020). The increase in machine learning methods, especially with a focus on language processing, allows handling information through textual social media data based on artificial intelligence analysis (GÉRON, 2019; CRUZ-CÁRDENAS et al., 2021) to help retailers to make better decisions.

New business models are growing and achieving prominence in online consumption with artificial intelligence, which has increased rapidly. Just as analytical techniques have been developed to analyze text data, the analysis of video or image content should have its techniques evolved based on machine learning (YANG et al., 2020). The virtual world is becoming more interesting than the physical world for consumers due to video games, virtual sports, among others. The pandemic has increased the use of social media on Facebook, Instagram, Whatsapp, Twitter, and WhatsApp. These social media generate a lot of data, like word of mouth. Technological advances need to be made by analyzing the videos. Most of the analysis focused on the text. So, future technologies using machine learning and artificial intelligence (SHETH, 2020) can contribute as retailers in understanding consumer reactions concerning videos posted about determining products. Currently, using artificial intelligence, customer data, images from monitoring cameras, and other digital clues, the Chinese government has created the Chinese citizen score to reward or punish individuals (KIRK; RIFKIN, 2020). 


\subsection{DATA SECURITY ON THE INTERNET}

The agile interaction and exchange of information in social networks produce consumers' digital "footprints", which can be tracked and combined with other information using data mining tools. It is worth mentioning that cyber-attacks are a cause of great concern, both for companies or governments and for the people who use the technology. Data security is a challenge for all industries that benefit from online resources, and most consumers say they are concerned about reliability and security in the overall online environment (BAICU et al., 2020; KHAIRUNESA, 2020; KIRK; RIFKIN, 2020).

For Kirk and Rifkin (2020), monitoring the Chinese citizen through apps based on government requirements is an example of losing privacy for the people who use the apps. Furthermore, the government determines who should be in mandatory quarantine, using the GPS (Global Positioning System) function to monitor their movement, demonstrating the potential that these resources have, placing individuals' privacy in doubt. That is why Donthu and Gustafsson (2020) emphasized that people should be aware that routines and infrastructures have been implemented to monitor them to contain the dissemination of COVID-19, but after that, how will be the acceptance of this monitoring? Will we continue to be tolerant of this type of practice performed by governments or organizations?

Retailers and businesses must understand the risk perceived by customers in transactions. In other words, the risk of infections due to COVID-19 in any purchase, fraud, and misuse of data in e-commerce transactions can also impact the purchasing behavior of consumers (SHIN, KANG, 2020; CRUZ-CÁRDENAS et al., 2021). In this way, companies can reduce consumers' perception of risk in online transactions via security protocols by incorporating and combining technologies to communicate these available tools to customers. So, managers can appropriate the technology to transmit to the consumer the business image that adds security and confidence in transactions (LV et al., 2020; CRUZ-CÁRDENAS et al., 2021; TROISE et al., 2021).

\subsection{ONLINE MARKETING AND PURCHASING PLATFORMS}

Online marketing is one of the keys to maintaining the profitability of companies during the pandemic. For Donthu and Gustafsson (2020), digital technology adoption, whether through online services or information sharing or communication platforms such as Zoom or Teams, has kept people connected worldwide. Samsung has programmed actions to leverage online sales to compensate for the closure of physical stores and has sought partnership with payment technology companies to create an e-commerce platform capable of maintaining sales and delivering directly to consumers (DONTHU; GUSTAFSSON, 2020). 
The use of online resources to make purchases and operationalize digital marketing is on the rise, with the support of digital platforms, intelligent technologies, and the help of analysis and decision-making with big data resources. Thus, traditional companies shape consumer behavior to adhere to "online", as it is possible to find all the items you want on an online trading platform without the need to move from one store to another to compare price and quality. As a result, the increase in online advertisements on social networks affects consumer purchasing decisions (KHAIRUNESA, 2020; SAFARA, 2020; VAN KIEN et al., 2020; YANG et al., 2020).

Online marketing plays a key role for companies already operating in this way, complementing the digital technologies approach and their impact on the economy and consumer behavior. Even for companies that do not yet operate but are thinking about migrating to digital platforms, it can be an opportunity (KOETZ, 2005). Understanding digital, or the digital process transformation, is necessary for companies that think about innovation and ways to diversify or expand their market performance.

Based on the research findings and responding to its objective (to understand the impacts that the COVID-19 pandemic caused on consumer habits and behavior from a literature review), the Table 2 presents the main aspects identified. Thus, it was possible to evidence that the "E-commerce growth" was the aspect that stood out the most among the others (70\%), followed by "panic buying: food and other products stock during the pandemic" (43\%) and "repressed demand and stricken" (37\%).

Table 2 - Main topics identified in the studies (articles)

\begin{tabular}{|c|c|c|}
\hline Topics Identified & $\%$ & Topics Identified and Articles Coding $(*)$ \\
\hline E-commerce growth & $70 \%$ & $\begin{array}{l}\text { A1 |A3 |A6 |A8 |A9|A10|A11 |A12 |A13 |A14 |A15 |A17 |A18|A19| } \\
\text { A21 |A23 |A24 |A25 |A26 |A28 |A29 }\end{array}$ \\
\hline $\begin{array}{l}\text { Panic buying: food and other products stock } \\
\text { during the pandemic }\end{array}$ & $43 \%$ & A1 |A3|A4 |A5 |A6 |A7 |A10|A11|A12 |A17|A18|A19|A30 \\
\hline Repressed demand and stricken sectors & $37 \%$ & A4 |A5 |A7 |A9 |A11 |A13 |A16 |A23 |A24 |A26 \\
\hline Apps (on-line shopping, mobile banking) & $27 \%$ & A1 |A2 |A9|A17|A21 |A24 |A28 |A29 \\
\hline $\begin{array}{l}\text { Online marketing, digital and purchasing } \\
\text { platforms }\end{array}$ & $20 \%$ & A1 |A8 |A14 | A24 |A28 |A29 \\
\hline Do-it-yourself & $17 \%$ & A3 |A4 |A11|A12 |A19 \\
\hline $\begin{array}{l}\text { Machine learning method and artificial } \\
\text { intelligence }\end{array}$ & $13 \%$ & A1 $\mid$ A3 |A4 |A9 \\
\hline Internet data security & $13 \%$ & A2 $|A 3| A 5 \mid A 8$ \\
\hline
\end{tabular}




\section{FINAL CONSIDERATIONS}

The evidence from this research indicates that the COVID-19 pandemic and the need for social distancing altered consumer habits and behaviors. The central question of this paper tried to reach the impacts of the COVID-19 pandemic from March 2020 and may still be causing consumer behavior nowadays. This research presents the main changes in consumer behavior arising from the pandemic scenarios in the period 2020-2021. Furthermore, this study tried to attain which consumer behaviors are likely to continue to happen, intensify, or will probably end as a post-pandemic to comprehend which trends customers will adopt. Also, arising from this disruptive event, the COVID-19 pandemic, some routes can be traced to managers marketing researchers, and consumer behavior.

The COVID-19 crisis is dynamic. Governments suspend lockdown measures as mass vaccination advances. However, few studies have been carried out on social and cultural problems during and after the COVID-19 crisis (CRUZ-CÁRDENAS et al., 2021). Soon, since vaccination is beginning as a breath of fresh air in this unprecedented crisis, a condition of "normality" may return. So, many habits and behaviors acquired during this period will compose a new consumer behavior. Customers deal with technological development based on the availability and facility to purchase food from apps and receive meals at home. E.g., most customers avoid closed environments in restaurants out of fear of new contamination, and the idea is to go out to a place to have a meal. However, going out to a restaurant to have a meal, with the security of being in safety place, outdoors, with the sanitized environment, can cause an experience of consumption more pleasant to the customer, who regains the "freedom" to interact in society, seeing friends and family in person again.

Panic buying behavior or storable goods happened at the beginning of the pandemic and lasted for a few months during the lockdown moments. An increase in the prices of products and services is a reflection of the pandemic because the scarcity due to high demands, the impediment of some productive sectors to carry out their activities, caused shortages in the market. As a result, prices are still high compared to March 2020. However, day-by-day it is possible to notice that non-essential goods demands (repressed demands) begin to react and survive despite the difficulties from some moments lived in pandemic moments.

Among other evidence, this survey pointed to the increase in online shopping, the expansion of services in the virtual environment, and how consumers quickly adapted to these new conditions. Therefore, companies, governments, managers, and researchers must keep up with this "new normal" being created. Virtual commerce, mainly through the m-commerce users, brought greater agility, personalization of service, and security in transactions for consumers. For Wang et al. (2015) and Omar et al. (2021), mobiles 
have become devices of customers' daily life, improving interactions and serving consumers anytime and anywhere. Therefore, as a contribution of this study, it is possible to point out that m-commerce is a "no return" shopping format where managers, retailers, and researchers must take ownership of this new shopping platform, which will intensify more and more every day.

Even before the pandemic, online and mobile services were already widely used but still met with much resistance in society. This moment imposed the adaptation to these tools, and many paradigms were overcome. After the pandemic, the levels of use of this type of resource will remain high due to the reliability and convenience perceived by users and the confidence acquired, which caused changes in consumer habits and buying and consumption behavior. So, as pointed out from Shin and Kang (2020) and Cruz-Cárdenas et al. (2021), retailers should understand the risk perceived by customers in transactions. As a contribution of this paper, people are more likely to feel fear in times of pandemics. In this ambiance, companies should prioritize mechanisms to convey greater security to customers. So, researchers, companies, and managers must create protocols and tools; that ensure safety, tranquility, and trust to customers.

As suggestions for the development of future research, based on the findings of this study, it is suggested to researchers a careful look at the information presented and how consumers and companies will behave in the context of a "new normal" from the worldwide vaccination, and a possible postpandemic context. Moreover, as limitations of the research, it is essential to emphasize the short time in which consumers are exposed to the pandemic, given the specialists' analyses and projections. Based on the evidence presented and its managerial implications, it is possible to consider that the impacts of the COVID-19 pandemic on consumer habits and behavior were discussed in this study, providing an empirical-theoretical basis for new studies that generate relevant information to support business strategies to be developed by managers.

\section{ACKNOWLEDGMENT}

The authors would like to thank the reviewer $A$ and $B$ for his/her constructive feedback that helped to improve the manuscript. Also, we would like to thank the Editor-in-chef professor Dra. Cristine Hermann Nodari. 


\section{REFERENCES}

ANASTASIADOU, E.; ANESTIS, M. C.; KARANTZA, I.; VLACHAKIS, S. The coronavirus' effects on consumer behavior and supermarket activities: insights from Greece and Sweden. International Journal of Sociology and Social Policy, v. 40, n. 9/10, p. 893-907, 2020.

ANTONIDES, G.; VAN LEEUWEN, E. Covid-19 crisis in the Netherlands: only together we can control Corona. Mind \& Society, article in press, 2020.

BARNES, S. J.; DIAZ, M.; ARNABOLDI, M. Understanding panic buying during COVID-19: a text analytics approach. Expert Systems with Applications, p. 114360, in press, 2020.

BAICU, C. G.; GÂRDAN, I. P.; GÂRDAN, D. A.; EPURAN, G. The impact of COVID-19 on consumer behavior in retail banking: evidence from Romania. Management \& Marketing -Challenges for the Knowledge Society, v. 15, n. 1, p. 534-556, 2020.

BRYNJOLFSSON, E.; HU, Y. J.; RAHMAN, M. S. Competing in the age of omnichannel retailing. MIT Sloan Management Review, Summer 2013.

COCOLAS, N.; WALTERS, G.; RUHANEN, L.; HIGHAM, J. Consumer attitudes towards flying amidst growing climate concern. Journal of Sustainable Tourism, ahead of print, p. 1-14, 2020.

CRUZ-CÁRDENAS, נ.; ZABELINA, E.; GUADALUPE-LANAS, נ.; PALACIO-FIERRO, A.; RAMOS-GALARZA, C. COVID-19, consumer behavior, technology, and society: a literature review and bibliometric analysis. Technological Forecasting \& Social Change, v. 173, n. 121179, 2021.

DIRSEHAN, T.; CANKAT, E. Role of mobile food-ordering applications in developing restaurants' brand satisfaction and loyalty in the pandemic period. Journal of Retailing and Consumer Services, v. 62, $102608,2021$.

DONTHU, N.; GUSTAFSSON, A. Effects of COVID-2019 on business and research. Journal of Business Research, v. 117, n. 12, p. 284-289, 2020.

DSOUZA, D.; SHARMA, D. Online food delivery portals during COVID-19 times: an analysis of changing consumer behavior and expectations. International Journal of Innovation, Science, already-to-print, 2020.

ELLISON, B.; MCFADDEN, B.; RICKARD, B. J.; WILSON, N. L. W. Examining food purchase behavior and food values during the COVID 19 pandemic. Applied Economic Perspectives and Policy, Special Collection on COVID-19, p. 1-15, 2021. 
ERDELEN, W. R.; RICHARDSON, J. G. A world after COVID-19: business as usual, or building bolder and better? Global Policy, p. 1-10, 2021.

FEDORKO, I.; BACIK, R.; GAVUROVA, B. Technology acceptance model in e-commerce segment. Management \& Marketing: Challenges for the Knowledge Society, v. 13, n. 4, p. 1.242-1.256, 2018.

GABRIEL, D.; LOREDANA, D. Using Internet as a solution for sales in Covid-19 pandemic: e-commerce. In: Annals of DAAAM \& Proceedings, v. 7, n. 1, p. 104-110, 2020.

GELBER, M. S. Do-it-yourself: constructing, repairingand maintaining domestic masculinity. American Quarterly, v. 49, n. 1, p. 66-112, 1997.

GÉRON, A. Hands-on machine learning with scikit-learn, keras, and tensorflow. $2^{\text {nd }}$ edition. Vancouver: O'Reilly, Sebastopol, 2019.

GOOLSBEE, A.; SYVERSON, S. F. Fear lockdown and diversion: comparing drivers of pandemic economic decline 2020. Journal of Public Economics, v. 193, n. 1, p. 104311, 2020.

HASSAN, S.; AWAN, M. T.; BHAUMIK, A. Covid-19 quarantine and consumer behavior that change the trends of business sustainability development. Academy of Strategic Management Journal, v. 19, n. 4, p. 1-11, 2020.

HENNINK, M.; HUTTER, I.; BAILEY, A. Qualitative research methods. Thousand Oaks: Sage Publications, 2011.

HOEKSTRA, J. C.; EEFLANG, P. S. H. Marketing in the era of COVID-19. Italian Journal of Marketing, v. 4, p. 249-260, 2020.

HOSSAIN, M. The effect of the COVID-19 on sharing economy activities. Journal of Cleaner Production, v. 280, p. 124782, 2021.

JRIBI, S.; ISMAIL, H. B.; DOGGUI, D.; DEBBABI, H. COVID-19 virus outbreak lockdown: what impacts on household food wastage? Environment, Development and Sustainability, v. 22, p. 3.939-3.955, 2020.

KHADEMI-VIDRA, A.; BUJDOSÓ, Z. Motivations and attitudes: an empirical study on DIY (do-it-yourself) consumers in Hungary. Sustainabiliy, v. 12, p. 1-19, 2020.

KAUR, A.; MALIK, G. Understanding the psychology behind panic buying: a grounded theory approach.

Global Business Review, p. 1-14, 2020. 
KERIGAN, N. The consumer in lockdown: consumer-merchant payments in a mobility-constrained environment. Journal of Payments Strategy \& Systems, v. 14, n. 2, p. 113-119, 2020.

KHAIRUNESA, I. Malaysians' popular online shopping websites during movement control order (MCO). International Journal of Advanced Trends in Computer Science and Engineering, v. 9, n. 2, p. 2.1542.158, 2020.

KINANGE, U.; PATIL, N. COVID-19 \& business environment: disruptions, opportunities and challenges. International Journal of Management and Applied Science, v. 6, n. 11, p. 19-23, 2020

KIRK, C. P.; RIFKIN, L. S. I'Il trade you diamonds for toilet paper: consumer reacting, coping and adapting behaviors in the COVID-19 pandemic. Journal of Business Research, v. 117, n. 11, p. 124-131, 2020.

KOETZ, C. I. O valor para o consumidor virtual - análise da utilização de internet por meio de web site de empresas. Gestão e Desenvolvimento, v. 2, n. 2, p. 35-46, 2005.

KOPYTIN, I. World oil market: the pandemics will bring global peak oil demand closer. World Energy After the Pandemic, v. 64, n. 9, p. 26-36, 2020.

LI, J.; HALLSWORTH, A. G.; COCA STEFANIAK, J. A. Changing grocery shopping behaviours among Chinese consumers at the outset of the COVID 19 outbreak. Tijdschrift Voor Economische en Sociale Geografie, v. 111, n. 3, p. 574-583, 2020.

LOXTON, M.; TRUSKETT, R.; SCARF, B.; SINDONE, L.; BALDRY, G.; ZHAO, Y. Consumer behaviour during crises: preliminary research on how coronavirus has manifested consumer panic buying, herd mentality, changing discretionary spending and the role of the media in influencing behaviour. Journal of Risk and Financial Management, v. 13, n. 8, p. 166-187, 2020.

LV, J.; WANG, Z.; HUANG, Y.; WANG, T.; WANG, Y. How can e-commerce businesses implement discount strategies through social media? Sustainability, v. 12, n. 18, p. 7.459, 2020.

McCLURE, R. J. After COVID-19, business as usual: is the right goal? Injury Prevention, v. 26, n. 3, p. 195, 2020.

McLEAN, G.; WILSON, A. Shopping in the digital world: Examining customer engagement through augmented reality mobile applications. Computers in Human Behavior, v. 101， p. 210-224, 2019.

OANA, D. The impact of the current crisis generated by the COVID-19 pandemic on consumer behavior.

Studies in Business and Economics, v. 15, n. 2, p. 85-99, 2020. 
OMAR, S.; MOHSEN, K.; TSIMONIS, G.; OOZEERALLY, A.; HSU, J. H. M-commerce: The nexus between mobile shopping service quality and loyalty. Journal of Retailing and Consumer Services, v. 60, n. $102468,2021$.

ORTEGA-VIVANCO, M. Efectos del Covid-19 en el comportamiento del consumidor: caso Ecuador. RETOS - Revista de Ciencias de la Administración y Economía, v. 10, n. 20, p. 233-247, 2020.

PAYNE, A.; STORBACKA, K.; FROW, P. Managing the co-creation of value. Journal of the Academy of Marketing Science, v. 36, n. 1, p. 83-96, 2008.

PRENTICE, C.; CHEN, J.; STANTIC, B. Timed intervention in COVID-19 and panic buying. Journal of Retailing and Consumer Services, v. 57, p. 102203, 2020.

RAMDHANI, A.; RAMDHANI, M. A.; AMIN, A. S. Writing a literature review paper: a step-by-step approach. International Journal of Basics and Applied Sciences, v. 3, n. 1, p. 47-57, 2014.

RAO, S.; TROSHANI, I. A conceptual framework and propositions for the acceptance of mobile services. Journal of Theoretical and Applied Electronic Commerce Research, v. 2, n. 2, p. 61-73, 2007.

REMLER, D.; VAN RYZIN, G. G. Research methods in practice: strategies for description and causation. Thousand Oaks: Sage Publications, 2011.

RUSSELL, J. Z.; CHERYL, B. COVID-19 generation: a conceptual framework of the consumer behavioral shifts to be caused by the COVID-19 pandemic. Journal of International Consumer Marketing, v. 33, n. 1, p. 58-67, 2021.

SAFARA, F. A computational model to predict consumer behavior during COVID-19 pandemic. Computational Economics, p. 1-14, 2020.

SCOTT, G.; GARNER, R. Doing qualitative research: designs, methods, and techniques. $1^{\text {st }}$ edition. Upper Saddle River: Pearson, 2013.

SEILER, P. Weighting bias and inflation in the time of COVID-19: evidence from Swiss transaction data. Swiss Journal of Economics Statistics, v. 156, n. 13, p. 1-11, 2020.

SHETH, J. Impact of Covid-19 on consumer behavior: will the old habits return or die? Journal of Business Research, v. 117, p. 280-283, 2020. 
SHIN, H.; KANG, J. Reducing perceived health risk to attract hotel customers in the COVID-19 pandemic era: focused on technology innovation for social distancing and cleanliness. International Journal of Hospitality Management, v. 91, n. 102664, 2020.

SMITH, J. A.; WELLS, L.; GELBART, L.; LAWSON, T. Beyond COVID-19: consumers call for greater focus on health equity. Health Promotion Journal of Australia, v. 32, n. 1, p. 3-5, 2021.

SNYDER, H. Literature review as a research methodology: an overview and guidelines. Journal of Business Research, v. 104, p. 333-339, 2019.

SOSCIA, I. Emotions and consumer behaviour. Cheltenham: Edward Elgar, 2013.

STATISTA. Mobile commerce in the United States. Available at: https://www.statista.com/study/12458/ mobile-commerce-statista-dossier/. Accessed on: 19 September 2021a.

STATISTA. Year-over-year daily change in seated restaurant diners due to the coronavirus (COVID-19) pandemic worldwide from February 24, 2020 to September 11, 2021. Available at: https://www. statista.com/statistics/1103928/coronavirus-restaurant-visitation-impact/. Accessed on: 19 Setember 2021b.

TORRACO, R. J. Writing integrative literature reviews: guidelines and examples. Human Resource Development Review, v. 4, n. 3, p. 356-367, 2005.

TROISE, C.; O'DRISCOLL, A.; TANI, M.; PRISCO, A. Online food delivery services and behavioural intention - a test of an integrated TAM and TPB framework. British Food Journal, v. 132, n. 2, p. 664-683, 2021.

TUPIKOVSKAJA-OMOVIE, Z.; TYLER, D. Clustering consumers' shopping journeys: eye tracking fashion m-retail. Journal of Fashion Marketing and Management, v. 24, n. 3, p. 381-398, 2020.

VAN KIEN, P.; THI, T. H. D.; LE, T. H. H. A study on the COVID-19 awareness affecting the consumer perceived benefits of online shopping in Vietnam. Cogent Business \& Management, v. 7, n. 1, p. 1-16, 2020.

WANG, R. J.; MALTHOUSE, E. C.; KRISHNAMURTHI, L. On the go: How mobile shopping affects customer purchase behavior. Journal of Retailing, v. 91, n. 2, p. 217-234, 2015.

WANG, Y.; XU, R.; SCHWARTZ, M.; GHOSH, D.; CHEN, X. COVID-19 and retail grocery management: insights from a broad-based consumer survey. IEEE Engineering Management Review, v. 48, n. 3, p. 202$211,2020$. 


\section{Gestãoe \\ Desenvolvimento}

e-ISSN: 2446-6875

p-ISSN: $1807-5436$

WILLIAMS, C. A lifestyle choice? Evaluating the motives of do-it-yourself (DIY) consumers. International Journal of Retail \& Distribution Management, v. 32, n. 5, p. 270-278, 2004.

YANG, X.; JIANG, J.; HAN, X. The impact of new epidemic situation on short-term choice and long-term upgrading of consumer behavior. In: ICWCSG - International Conference on Wireless Communications and Smart Grid, p. 382-385, 2020. 